\title{
フランジ付き点火プラグの基本特性と天然ガスエンジンへの応用*
}

$$
\begin{gathered}
\text { 氏 家 康 成*1, 江 間 佑 二*2 } \\
\text { 野 村 浩 司*1, 鳥 居 将 行*3 }
\end{gathered}
$$

\section{Research on the Fundamental Property of Flanged Spark Plug and Application to Natural Gas Engine}

\author{
Yasushige UJIIE*4, Yuji EMA, \\ Hiroshi NOMURA and Masayuki TORII \\ ${ }^{* 4}$ Department of Mechanical Engineering, College of Industrial Technology, Nihon University, \\ 1-2-1 Izumicho, Narashino-shi, Chiba, 275-8575 Japan
}

\begin{abstract}
Spark ignition characteristics of flanged spark plugs have been studied experimentally. Experiments were performed using a constant volume combustion chamber and a natural gas engine. Flanged spark plugs were made by remolding spark plugs on the market. The minimum ignition energy was employed to evaluate the ignition characteristics of the flanged spark plugs. It was found that the flanged spark plug reduces the minimum ignition energy. It was observed by schlieren photography that the shock wave was reflected by the flanges concentrated on a flame kernel. This fact suggests that the adiabatic compression due to the shock concentration reduces the minimum ignition energy. There is little effect of the flange on the flame speed, although it is well known that the existence of flanges prevents the initial growth of the flame kernel. It was found that, in actual engine test, the ignition probability is increased and the lean limit is extended.
\end{abstract}

Key Words : Ignition, Combustion, Spark Ignition, Flanged Spark Plug, Shock Wave, Natural Gas Engine

\section{1. 緒 言}

現在, 自動車用火花点火機関では, 燃料消費率の低 减や排気ガス浄化の目的から希薄燃焼が指向されてい る. 希薄混合気を用いる上で，燃焼室内の強い乱れは 火炎伝播速度の促進に有効である反面，火炎核の熱損 失が増大して点火は困難になる. その対策として, 火 花エネルギ一を増大させて失火を回避しているが，点 火系の早期劣化や電磁波障害 (EMI) が懸念されるこ とから，点火エネルギ一の低減は重要な課題の一つで ある. 過去に定容燃焼容器を用いた基礎実験を行い， 火花電極に 2 枚のフランジを並行に設置し，火花放電 時に発生する衝撃波のエネルギ一を反射・回収するこ とが，最小点火エネルギ一低减に有効であるという報 告がされている1)2.

そこで本研究では実機への応用を念頭に置き，点火 プラグの接地電極にフランジを設置し，定容燃焼容器

* 原稿受付 2003 年 3 月 17 日.

*1 正員, 日本大学生産工学部(-275-8575 習志野市泉町 1-21).

*2 日本大学大学院生産工学研究科.

*3 セントラルエンジニアリング(株) (恶100-0005 東京都千代 田区丸の内 2-2-1 岸本ビル 511 号).

E-mail : ujiie@cit.nihon-u.ac.jp
内の静止混合気中で点火実験を行ったところ, 同様に 最小点火エネルギーの低减効果が確認された。 さらに ガソリンエンジンに比べて点火条件の厳しいとされる 天然ガスエンジンを用い，フランジ付き点火プラグが 点火特性に与える影響を調べた.

\section{2. 実験装置および方法}

予備実験で用いた実験装置の概略を図 1 に示寸．定 容燃焼容器はステンレス鋼製の円筒形で, 燃焼室は直 径 $40 \mathrm{~mm}$, 厚さ $30 \mathrm{~mm}$ である. 燃焼容器の両端面に は衝撃波および火炎核の成長形態観察用に石英ガラス 空が取り付けてあり, シュリーレン光学系を設置した. 混合気の点火には自作の CDI 方式点火装置を用い, 容 量成分火花による点火実験を行った．混合気は 3.8 vol.\%プロパンー空気予混合気を用いた.

実機における実験装置の概略を図 2 に示す，供試機 関は，日産工機製 H25 型ガソリンエンジンに天然ガ スを燃料として用いた．供試機関の主な諸元は直列 4 気筒，排気量 $2472 \mathrm{cc，ボア×ストローク} 92.0 \mathrm{~mm} \times$ $93.0 \mathrm{~mm}$, 圧縮比 8.7 である. 燃料である天然ガスは Governor-zero によって大気圧に調圧され，層流形流 
量計により燃料流量を計測したのち, 混合器に吸入さ れる. またメイン・アジャスト・スクリューにより燃 料流量を調整し, 混合気濃度を設定した。吸入空気流 量測定も層流形流量計を用いた. 燃焼室内の圧力履歴 を測定するため, 燃焼室の 1 つに圧力センサを取り付 け,ストレージオシロスコープに圧力波形を記録した。

図 3 に定容燃焼容器用フランジ付き点火プラグと実 機用フランジ付き点火プラグを示す. 定容燃焼容器に 用いたフランジ付き点火プラグは, 市販のプラグ (NGK 製 B8EVX) の接地電極を取り外し, 新たに接 地電極およびフランジを設置した. 天然ガスエンジン で使用したフランジ付き点火プラグは, 市販のプラグ （NGK 製 B4ES）を加工し，フランジの脱落を防ぐ ためステンレス鋼製の線材 3 本でねじ止めした後， 万 う付けを施した. フランジ直径を 7,9mm で変化させ, フランジ間隔は定容然焼容器用プラグでは $2 \sim 10 \mathrm{~mm}$ に, 実機用プラグではフランジ直径 $9 \mathrm{~mm}$ では 4〜 $8 \mathrm{~mm}$ に, フランジ直径 $7 \mathrm{~mm}$ では $2.5 \sim 6 \mathrm{~mm}$ に変化 させ, 点火確率を求めた. また, 定容燃焼容器を用い た実験では，点火エネルギーの測定には火花電極間の 電圧波形と電流波形からエネルギーを求める電気的測 定法を用いた. 点火確率は点火回数 30 を点火に要し た火花放電回数で除した值とし, 点火確率 $50 \%$ 時の点 火エネルギーを最小点火エネルギーと定義した. 実機 では点火確率 $90 \%$ 程度でエンジンの不調を聴感で察 知したため, 最小点火エネルギーの定義は行わなかっ た. 実機での点火確率を求めるにあたっては, 以下の 手順によった. 点火確率 $100 \%$ を保てる最低当量比の 運転状態で, 正味平均有効圧力 $0.3 \mathrm{MPa}$, 機関回転速 度 2000r.p.m. を設定した. ついで, 順次当量比を低下 させ, 放電回数 300 回のうちの点火回数を測定し算出 した.このとき初圧が大気圧時の圧縮終圧を目安とし, 燃焼最大圧力が $2.0 \mathrm{MPa}$ より低いものを失火とみなし た.

\section{3. 定容燃焼容器における 実験結果および考察}

フランジ直径 $9 \mathrm{~mm}$ において, フランジ間隔を 2〜 $10 \mathrm{~mm}$ に変化させたときの最小点火エネルギーと点 火確率の関係を図 4 に示す. 横軸は点火エネルギー, 縦軸は点火確率を示し, フランジ間隔を副変数として 用いた、いずれの場合においても，点火エネルギーの 増加とともに点火確率は増大しており, フランジ付き プラグがフランジなしプラグの点火確率よりも高くな っていることがわかる. この理由として, フランジに

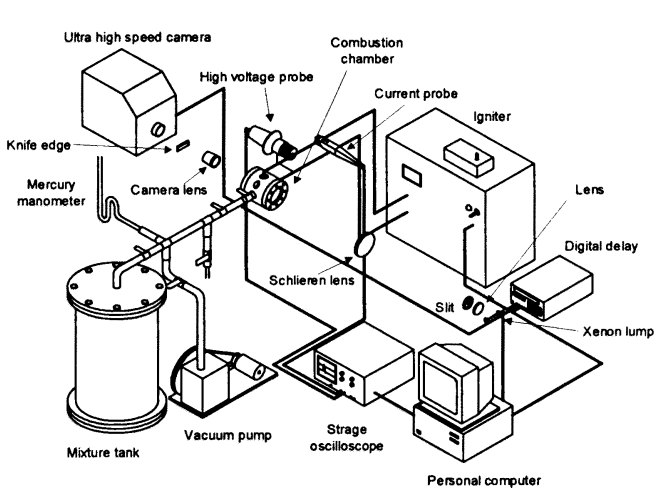

Fig. 1 Experimental apparatus for constant volume combustion chamber

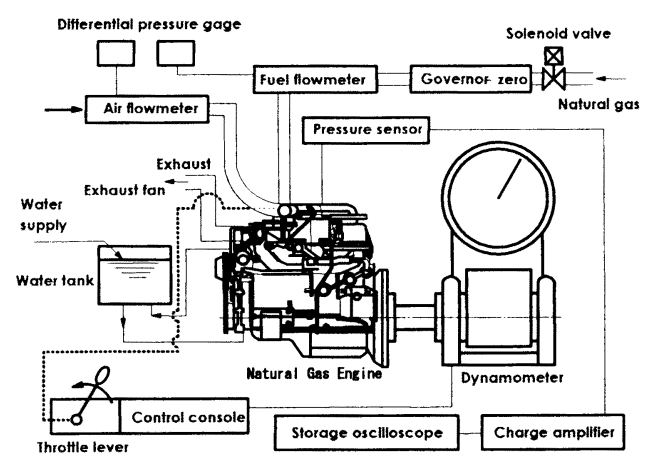

Fig.2 Experimental apparatus for natural gas engine

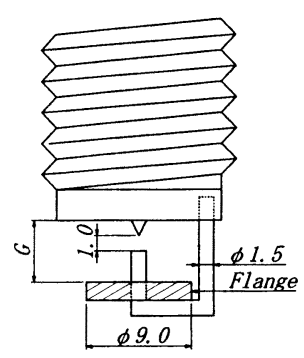

(a) for combustion chamber

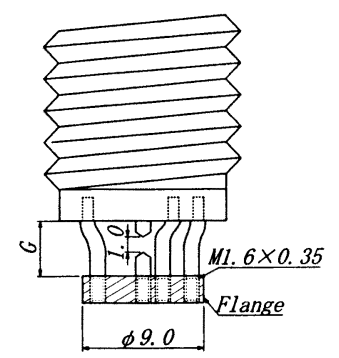

(b) for actual engine
Fig. 3 Flanged spark plugs

より衝撃波が反射されたことによって，火炎核に干涉 する位置で断熱圧縮が起こり，本来なら周囲に発散す るはずの衝撃波のエネルギーを一部熱エネルギーとし て回収しているためと考えられる.フランジ間隔が狭 いほど, 衝撃波の散逸領域の减少や反射距離低减の関 係で回収できるエネルギーが大きくなると考えられる. 本実験範囲では火炎核からフランジへの熱損失の影響 
は小さいと思われるが, フランジ間隔 $2 \mathrm{~mm}$ 未満では 最小点火エネルギーが急増することを確認している。

図 5 にフランジ直径 $9 \mathrm{~mm}$, フランジ間隔 $5 \mathrm{~mm}$ に おけるフランジ付き点火プラグの衝撃波の成長形態を 示す. 火花放電時を $0 \mu \mathrm{s}$ とし, Frame Rate は $1 \mu \mathrm{s}$ とした. 火花放電時に発生した衝撃波がフランジによ り反射を繰り返し，火炎核に干渉していることがわか る. 衝撃波の進行に伴ってそのエネルギーは減衰する ため, フランジ間隔が狭いほど減衰前の高エネルギー 時に反射することができ，有效にエネルギーが回収さ れるものと考えられる. またフランジ間隔が狭いこと で, フランジ間陌からの衝撃波の散冕割合が減少する ため, エネルギーの回収効果が高いと考えられる。こ のことは過去のフランジ付き電極による基礎実験にお いて, フランジ間隔が小さくなるにつれ最小点火エネ ルギーが低減されたことにより確認されている 2)。し かしながら, 図 4 ではフランジ間隔 $3,4 \mathrm{~mm}$ におい てその傾向が逆転している，原因解明のため, 過去の 基礎実験で行ったフランジ付き電極における衝撃波の シュリーレン写真と比較して考察する.

図 6 にフランジ間隔 $5 \mathrm{~mm}$ におけるフランジ付き電 極の衝撃波の成長過程を示す. 火花放電後衝撃波が発 生し，2つのフランジより反射された衝撃波は火花間 隙に対し刘照的となっている. そのため両フランジか ら反射された衝撃波は同時に火炎核に干渉しており，

図 5 と比較寸るとより効果的に衝撃波のエネルギーを 回収していると推定される.したがって図4において フランジ間隔と点火確率が一様な関係にならない理由 として, 図 6 のフランジ付き電極を用いた実験では 2 枚のフランジを火花間隙から等距離に配置していたの に対し，本実験では接地電極側のみにフランジを配置 したため, 中心電極側ではプラグのねじ部端面と中心 電極絶縁体に上って衝撃波が反射され, 複雑な反射を 起こしてエネルギーの回収率が低下したからであると 考えられる.

図 7 にフランジ間隔が最小点火エネルギーに及ぼす 影響について示す，縦軸は最小点火エネルギー, 横軸 はフランジ間隔である. フランジ直径を副変数とし, フランジがない場合の值を破線で示す，図より，す心゙ ての条件においてフランジがない場合よりも最小点火 エネルギーは小さい值を示した。 このことより, フラ ンジによって衝撃波の持つエネルギーを回収すること で, 最小点火エネルギーを大幅に低減していることが 分かる. また各フランジ直径において, フランジ閒隔 $2 \mathrm{~mm}$ で最小点火エネルギーは最小值をとり, フラン ジ直径 $9 \mathrm{~mm}$ ではフランジ間隔 $3 \mathrm{~mm}$ で, フランジ直

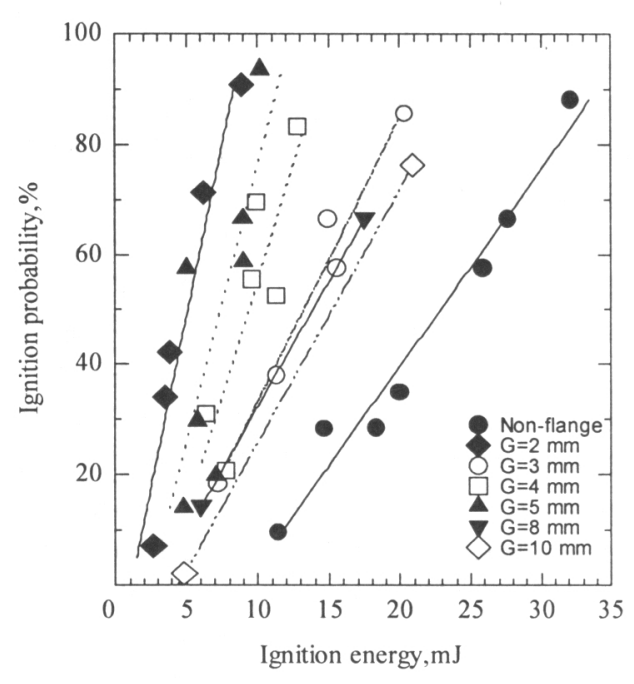

Fig. 4 Relation between ignition energy and ignition probability $(\phi=0.94)$

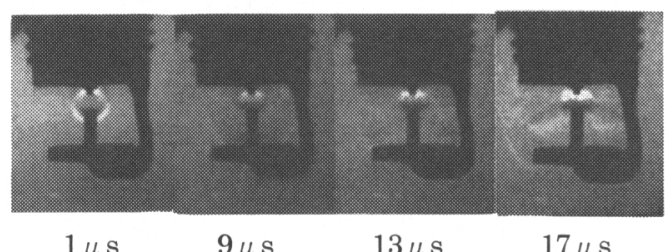

Fig.5 Schliren photographs of shock wave

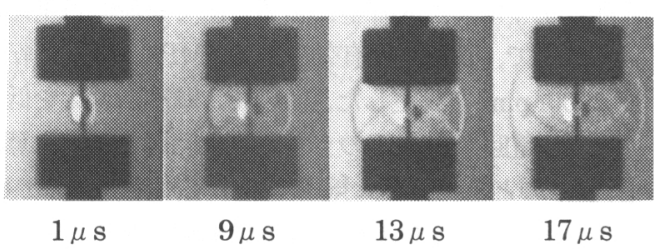

Fig.6 Schliren photographs of shock wave

径 $7 \mathrm{~mm}$ ではフランジ間隔 $4 \mathrm{~mm}$ で極大值を示し, フ ランジ間隔 $8 \mathrm{~mm}$ 以上で再び増加した. フランジ間隔 $2 \mathrm{~mm}$ で最小点火エネルギーが最小值を示寸理由，お よび極大值を示す理由は前述のとおりである. フラン ジ間隔 $8 \mathrm{~mm}$ 以上で再び増加寸るのは, フランジ間隔 が大きいため, フランジがない状態に近づいたことに よると考えられる. しかしながら, 過去のフランジ付 き電極での実験とは異なり, フランジがない場合の值 に漸近せずにある程度のエネルギー低减が見られる. これは, フランジ間隔が大きくなっても接地電極側フ ランジの位置が変化するだけで火花間隙中心と中心電 
極側フランジ面との位置関係が変化しないので，中心 電極側で反射する衝撃波の進行距離が変わらなく，あ る程度のエネルギー回収が行われるものと考えられる。 前述のとおり, フランジには最小点火エネルギーを 低减する効果がある反面, 熱損失のために火炎の成長 が抑制されていると考えられる. そこで燃焼時の圧力 履歷から燃焼所要時間を求めた。 燃焼所要時間は火花 放電から最大燃焼圧力までの時間と定義した. 図 8 に フランジ間隔が燃焼所要時間に及ぼす影響を示す。 火 花エネルギーはフランジなしの場合に合わせて $23.0 \pm$ $0.5 \mathrm{~mJ}$ に調整した。繸軸に燃焼所要時間, 横軸にフラ ンジ間隔を示し, 比較のためフランジなしプラグの值 を破線で示寸．図より，フランジ間隔が小さい範囲で はフランジなしプラグよりも燃焼所要時間は若干増大 した.これはフランジへの熱損失が影響したためと考 えられる. またフランジ間隔が大きい条件では, フラ ンジなしプラグよりも燃焼所要時間が若干減少してお り，フランジへの熱損失の影響が小さく、エネルギー 回収による火炎核の保温作用により火炎伝播が促進さ れたためと考えられる. また, フランジ端部による乱 れ発生が寄与していることも考えられる.いずれにし ても本実験範囲では，火炎核からフランジへの熱損失 の影響は小さいものと判断される.

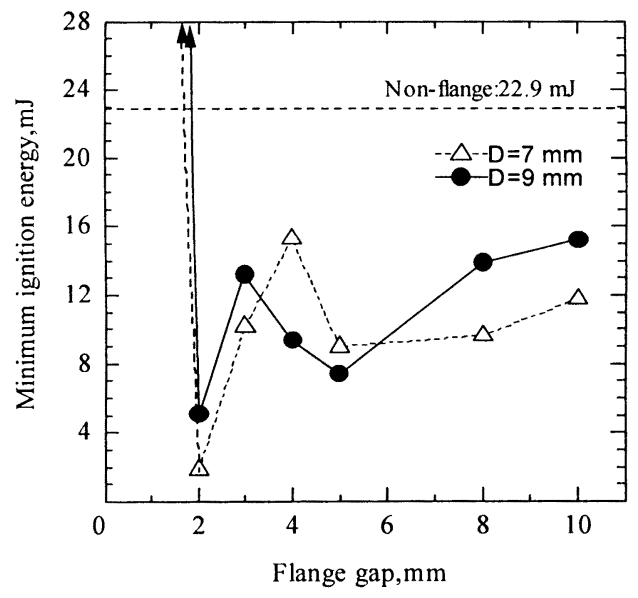

Fig.7 Relation between flange gap and minimum ignition energy $\quad(\phi=0.94)$

\section{4. 天然ガスエンジンにおける} 実験結果および考察

フランジ付きプラグを実機に適用した場合の，フラ ンジなしプラグおよびフランジ間隔 $4 \mathrm{~mm}$ における燃

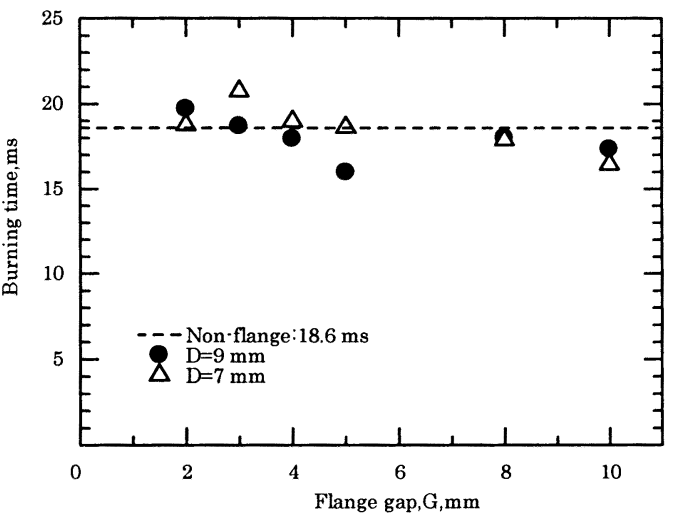

Fig.8 Relation between flange gap and burning time $(\phi=0.94)$

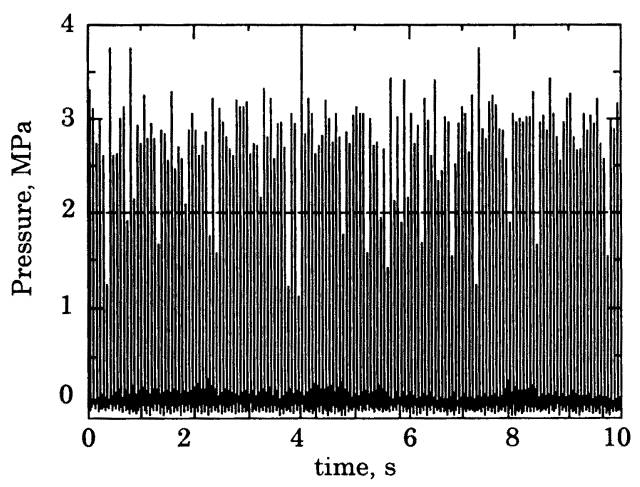

a) non-flange

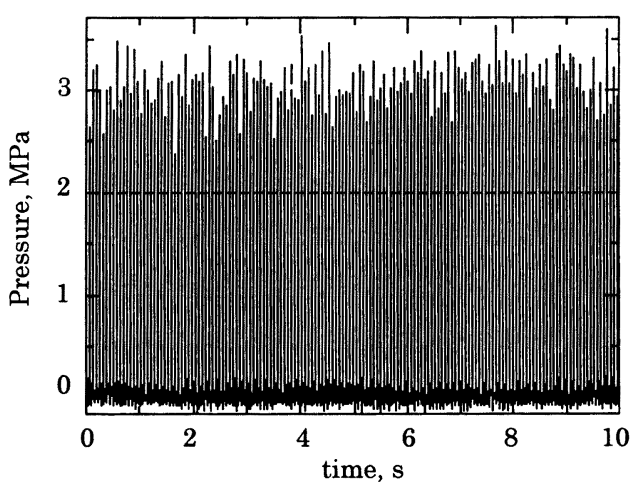

b) flanged plug $(G=4, D=9)$

Fig. 9 Indicated pressure history $(\phi=0.61)$

焼室内の圧力履歴を図 9 に示す. 綐軸に燃焼室内圧力, 横軸に時間を示し, 点火したとみなす $2.0 \mathrm{MPa}$ を破線 で示した(実測の圧縮終圧は $1.2 \mathrm{MPa}$ ). 当量比はいずれ 
も 0.61 である. フランジなしプラグではミスファイア を起こしており, 点火した場合でも圧力変動が大きい ことがわかる.これに対しフランジ付きプラグでは, すべて点火していることと圧力変動が小さいことがわ かり, 安定した燃焼が得られ, 希薄領域におけるフラ ンジ付き点火プラグの優位性が明らかである.

フランジ直径 $9 \mathrm{~mm}$ における当量比と点火確率の関 係を図 10 に示す. 横軸に当量比, 縦軸に点火確率を 示し, 副変数としてフランジ間隔を用いた. すべての プラグにおいて当量比の増加に従い点火確率が増大し ていることがわかる. フランジ間隔 $2 \mathrm{~mm}$ を除くフラ ンジ付きプラグにおいては, フランジなしプラグに比 べて高い点火確率を示していることから，実機の複雑 で強い乱れ場中で誘導成分を含んだ合成火花において も，フランジによる衝撃波のエネルギ一回収効果が得 られることがわかった. フランジ間隔 $2 \mathrm{~mm}$ において, およそ当量比 $\phi=0.63$ で通常プラグの值と交差し急 激に点火確率が減少していることから，フランジ間隔 $2 \mathrm{~mm}$ が消炎距離になったと考えられる. 過去のフラ ンジ付き電極での実験において，フランジ間隔を $2 \mathrm{~mm}$ よりも $0.1 \mathrm{~mm}$ 程度小さくしただけで消炎距離に 至り，点火確率が急激に減少したという報告がされて いる ${ }^{2)}$.

フランジ直径 $7 \mathrm{~mm}$ における当量比と点火確率の関 係を図 11 に示す. 綐軸に点火確率, 横軸に当量比を 示し,フランジ間隔を副変数とした. フランジ直径 $9 \mathrm{~mm}$ においてフランジ間隔 $2 \mathrm{~mm}$ が消炎距離となっ たため, フランジ直径 $7 \mathrm{~mm}$ ではフランジ間隔 $2.5 \mathrm{~mm}$ を作成して点火確率を求めた. 同図より，いずれのプ ラグにおいても図 10 と同様に当量比の増加に伴って 点火確率が増大していることがわかる. フランジ間隔 4 および $6 \mathrm{~mm}$ ではフランジなしプラグの值を上回っ ており, フランジ直径 $9 \mathrm{~mm}$ と同様にフランジ間隔 $4 \mathrm{~mm}$ で点火確率は最も高くなった。 フランジ間隔 $2.5 \mathrm{~mm}$ においては, フランジ直径 $9 \mathrm{~mm}$ でのフランジ 間隔 $2 \mathrm{~mm}$ と同様に, 当量比 0.64 から希薄側では急激 に点火確率が減少しており，消炎距離となったと思わ れる. フランジ間隔 4 および $6 \mathrm{~mm}$ ではフランジ直径 $9 \mathrm{~mm}$ における点火確率とほぼ同じ值を示しているこ とから, 定容燃焼容器における基礎実験と同様に, フ ランジ直径の影響は小さいと考えられる.

図 12 に当量比 0.57 における, フランジ間隔と点火 確率の関係を示す．縦軸に点火確率, 横軸にフランジ 間隔を示し，同一当量比におけるフランジなしプラグ の点火確率を破線で示した. 図より, すべてのフラン ジ間隔でフランジなしプラグの点火確率より

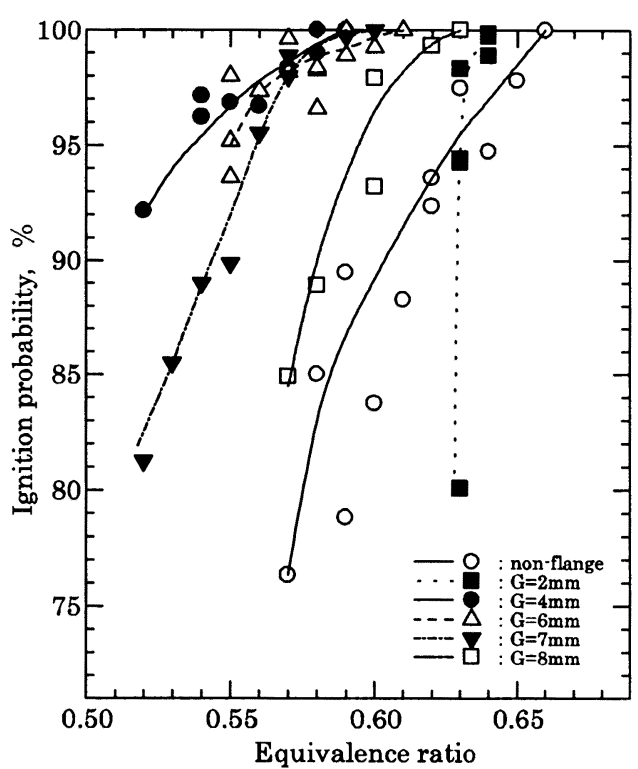

Fig.10 Relation between equivalence ratio and ignition probability $(D=9 \mathrm{~mm})$

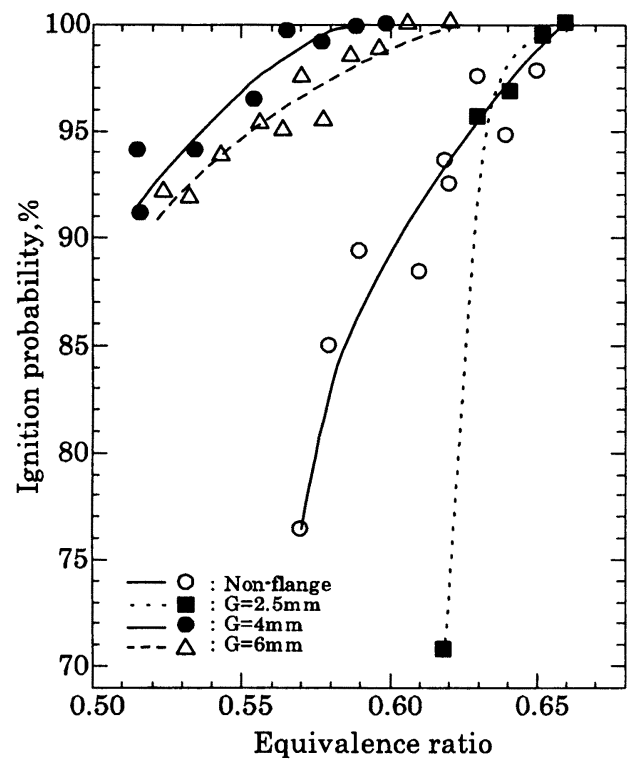

Fig.11 Relation between equivalence ratio and ignition probability $(\mathrm{D}=7 \mathrm{~mm})$

も高くなっていることが分かる. また，フランジ間隔 4〜 7mm の範囲では点火確率が高い值を示しており, $3 \mathrm{~mm}$ になると点火確率が減少している。これは，フ ランジ間隔が狭くなると火炎核からフランジへの熱損 
失が大きくなったためと考えられる．前項で述べたと おり，フランジ間隔 2 および $2.5 \mathrm{~mm}$ では急激に点火 確率が減少し, 当量比を 0.57 まで希薄にするとエンジ ンが停止して計測できなかったことからもこのことが 推測される. フランジ間隔 $8 \mathrm{~mm}$ において点火確率が 減少しているのは, フランジが火花間隙より遠くなつ たことで衝撃波の散逸領域が増し, また, 衝撃波進行 距離が増大して十分にエネルギーの回収がなされなか ったためと考えられる.

図 13 に各フランジ間隔におけるフランジ付きプラ グの点火エネルギーを示す．比較のため，フランジな しプラグの点火エネルギーを破線で示した．図より， 若干のばらつきはあるが，大きな差は認められなく， 同一火花エネルギーの下でフランジ付きプラグの特性 評価を実施したことが保証されている.

\section{5. 結 言}

予混合気の火花点火エネルギーを低減することを目 的として、定容燃焼容器および天然ガスエンジンを用 いてフランジ付き点火プラグの点火特性を調べた結果, 以下の知見を得た.

1. 点火プラグにフランジを設置することにより, 衝撃 波の持つエネルギーを効果的に回収することで最 小点火エネルギーを低减できる.

2. 定容容器を用いた静止混合気場では中心電極側で 衝撃波が複雑な反射をし，その影響で若干の差は あるがフランジ間隔 $3 \mathrm{~mm} \sim 4 \mathrm{~mm}$ で最小点火エ ネルギーは一旦極大值を示す.

3. フランジには, 衝撃波のもつエネルギーの回収およ び熱損失増大の背反する効果があるが，点火後の 火炎伝播速度にはあまり影響しない。

4. 実機の強乱れ場中で合成火花を用いても,フランジ の衝撃波エネルギ一回収効果は得られる.

5. 本供試機関においては, いずれのフランジ直径にお いてもフランジ間隔 $4 \mathrm{~mm}$ で最も高い点火確率を 示した.

6. フランジ間隔と点火確率は一様な関係となってお らず, フランジ間隔 $3 \mathrm{~mm}$ 以下および $7 \mathrm{~mm}$ 以上で 点火確率は减少する. 5.の結論とも関連して、実機 にフランジ付き点火プラグを適用する場合は、フ ランジ間隔を $4 \mathrm{~mm}$ とするのが適当であると判断 される。

最後に, 本研究の一部は平成 $14 \sim 15$ 年度文科省科 学研究費補助金 \{基盤研究（c）\}によるもので，供

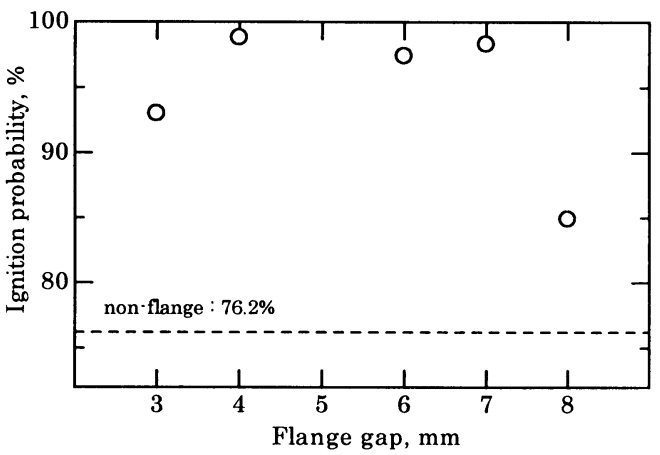

Fig.12 Relation between flange gap and ignition probability $(\phi=0.57)$

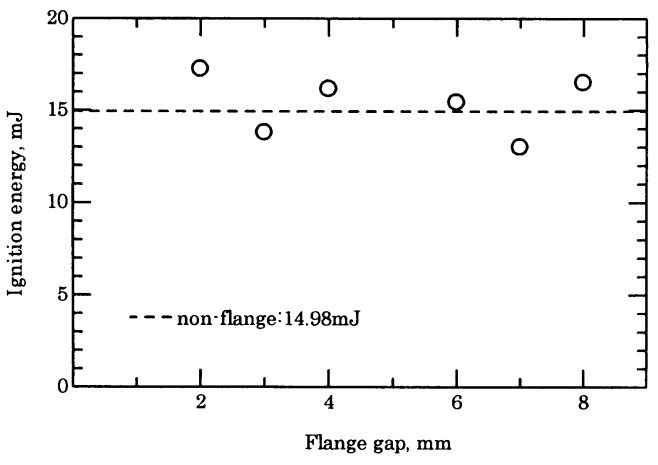

Fig.13 Spark energy for actual engine

試機関は日産工機(株)のご提供であることを付記し， ここに謝意を表する.

\section{参考文献}

1）三森, 平沼, 青木, 野村, 氏家, 河野 : 強乱れ場に おけるフランジ付き電極の点火特性, 機講論III, 96-1 (1996)，559-560

2）三森, 佐藤, 野村, 氏家, 河野 : フランジ付き電極 の火花点火エネルギ一低减に関する研究, 機講論 III, 97-1 (1997), 43-44 